\title{
HUBUNGAN FAKTOR ABIOTIK TERHADAP JUMLAH KLOROFIL DAN STOMATA (EKOFISIOLOGIS) PADA TANAMAN JATI (Tectona grandis L.f.) DI KABUPATEN MALANG \\ (Relationship of Abiotic Factors to Total of Chlorophyll and Stomata (Ecophysiological) in Teak Plant (Tectona grandis L.f.) at Malang District)
}

\section{Amir Syarifuddin ${ }^{1}$, Febri Arif Cahyo Wibowo ${ }^{1 *}$, Saddam Affandy Yusuf ${ }^{1}$ dan/and Agus Dwi Sulistyono 2}

\author{
${ }^{1}$ Jurusan Kehutanan, Fakultas Pertanian-Peternakan, Kampus III Universitas Muhammadiyah \\ Malang Jalan Raya Tlogomas No. 246, Tlp.: (0341) 464318 (Hunting); Fax: (0341) 460435 \\ Tlogomas, Malang, Jawa Timur 65144 \\ ${ }^{2}$ Jurusan Sosial Ekonomi Perikanan dan Kelautan, Fakultas Perikanan dan Ilmu Kelautan, \\ Universitas Brawijaya \\ Jln. Veteran Malang, 65145 Jawa Timur - Indonesia Tlp. : (0341) 553-512, Fax : (0341) 556-837 \\ Surel : faperik@ub.ac.i \\ *E-mail : febriarif14@gmail.com \\ Tanggal diterima: 10 November 2020; Tanggal disetujui: 3 Maret 2021; Tanggal direvisi: 3 Maret 2021
}

\begin{abstract}
Climate change due to increasing earth temperature is predicted to escalate plant stress chances. Changes in temperature followed by humidity changes will affect plant physiology, including the stomata index and chlorophyll. Both parts are essential for the photosynthesis process in the plant. This study aimed to determine whether abiotic factors influenced the physiological conditions of teak plants. Leaf samples were taken from six trees selected based on tree height (11-13 meters). Leaf samples were taken in the same direction north and south, 18 for the stomata sample and 18 for the chlorophyll sample, with three samples for the stomata and chlorophyll in each tree. Temperature and humidity observations were carried out for two months. The analysis used in this study was SEM-PLS analysis using warpls software. The results showed that temperature had a positive effect on the stomata index of 0.746. The significant negative effect was indicated by the effect of temperature on chlorophyll $a$, humidity on chlorophyll $b$ and humidity on total chlorophyll with values of $0.571,-0.688$ and -0.614 , respectively. The reduced environmental temperature has caused a reduction in photosystem activity, resulting in excessive chlorophyll production. The remedial solution is silvicultural techniques application in an appropriate plant spacing to reduce temperature and increase the humidity of the microclimate in the area.
\end{abstract}

Keywords: Ecophysiology, chlorophyll, stomata, abiotic factors

\begin{abstract}
ABSTRAK
Perubahan iklim akibat penambahan suhu bumi meningkatkan peluang stres tanaman. Perubahan suhu yang diikuti dengan perubahan kelembapan akan mempengaruhi fisiologi tanaman diantaranya indeks stomata dan klorofil, dimana keduanya merupakan bagian dalam proses penting tanaman, yakni proses fotosintesis. Tujuan penelitian ini adalah untuk mengetahui apakah kondisi fisiologis tanaman jati dipengaruhi oleh faktor abiotik. Pengambilan sampel daun dilakukan pada enam pohon yang dipilih berdasarkan tinggi pohon (11-13 m). Sampel daun diambil searah, yaitu utara dan selatan sebanyak 18 untuk sampel stomata dan 18 untuk sampel klorofil, dengan masing-masing tiga sampel untuk
\end{abstract}


stomata dan klorofil pada setiap pohon. Pengamatan suhu dan kelembapan dilakukan selama dua bulan. Analisis yang digunakan dalam penelitian ini adalah analisis SEM-PLS menggunakan software warpls. Hasil analisis menunjukkan bahwa suhu berpengaruh positif terhadap indeks stomata sebesar 0,746. Pengaruh negatif secara signifikan ditunjukkan oleh pengaruh suhu terhadap klorofil a, kelembapan terhadap klorofil b dan kelembapan terhadap klorofil total dengan nilai masing-masing -0,571, -0,688 dan -0,614. Suhu lingkungan berkurang mengakibatkan pengurangan aktivitas fotosistem, sehingga produksi klorofil berlebihan. Solusi perbaikan dengan penerapan teknik silvikltur dalam pengaturan jarak tanaman yang sesuai untuk menurunkan suhu dan meningkatkan kelembapan iklim mikro di kawasan.

\section{Kata kunci: Ekofisiologi, klorofil, stomata, faktor abiotik}

\section{PENDAHULUAN}

Penambahan suhu bumi sebagai pemicu global warming (Shu-yue et al., 2020) berdampak pada perubahan iklim (Tang, Ohashi, Matsui, \& Herrando, 2020), proses fotosintesis (Strobl et al., 2016) dan bukan stomata tanaman (Zweifel, Regling, \& Dobbertin, 2009). Hubungan antara fisiologi pohon dengan faktor lingkungan seperti faktor abiotik menjadi salah satu parameter untuk mengetahui bagaimana lingkungan dapat mendukung atau menurunkan aktivitas pertumbuhan pohon.

Pohon merespon kejadian atau fenomena yang terjadi di luar dengan berbagai macam respon. Salah satunya kondisi stres tanaman yang diakibatkan kejadian di luar (faktor abiotik) akan direspon oleh tanaman. Kondisi stres oleh faktor abiotik dengan peningkatan suhu direspon oleh pohon dengan penutupan stomata yang banyak dipengaruhi oleh gas $\mathrm{CO}_{2}$, suhu, kelembapan, cahaya, angin dan laju fotosintesis (Izza \& Laily, 2015); (Juairiah, 2014). Respon lainya adalah pemanfaatan klorofil sebagai salah satu tempat untuk proses fotosintesis melalui cahaya yang ditangkap oleh pigmen klorofil setiap unit area fotosintetik berdasarkan hasil rasio klorofil a/b (Karubuy, Rahmadaniarti, \& Wanggai, 2018) dan pemanfaatan klorofil b pada pohon di bawah naungan (Wibowo, Putri, Syarifuddin, \& Muttaqin, 2020) dimana pohon akan memanfaatkan klorofil a atau b untuk menangkap radiasi gelombang cahaya untuk fotosintesis (Ai Song \& Banyo, 2011).

Berbagai pohon merespon kondisi lingkungan untuk bertahan hidup, salah satu pohon yang unik di Indonesia adalah pohon jati (Tectona grandis L.f.). Di Indonesia yang memiliki dua musim, antara kemarau dan penghujan memberikan perilaku unik pada jati, dimana pada musim penghujan membentuk banyak daun, sedangkan musim kemarau menggugurkan daun. Hal ini menjadi fenomena yang berlangsung secara terus menerus pada jati dan sebagai bukti bahwa pohon merespon kondisi lingkungan untuk bertahan hidup. Peningkatan pertumbuhan pohon jati perlu ditingkatkan karena fenomena tersebut, akibat mengalami hambatan pada saat musim kemarau (pengguguran daun jati). Selain itu, gangguan lain dari tumbuhan parasit, seperti benalu yang sering ditemukan pada cabang/ranting jati dapat mengurangi penyerapan hara yang didistribusikan ke berbagai organ pohon (Hasanbahri, Marsono, \& Hardiwinoto, 2014) salah satunya distribusi unsur hara yang ada di daun (Supriyo \& Prehaten, 2014).

Berbagai upaya telah dilakukan untuk meningkatkan pertumbuhan pohon jati (Tectona grandis L.f.), diantaranya pengujian famili jati dan klon jati (Prehaten, Indrioko, Hardiwinoto, Na'iem, \& Supriyono, 2018; Widiatmaka, Merdiranto, \& Hermanu, 2015; Adinugraha \& Fauzi, 2015); pengujian pertumbuhan jati (Fitriani, 2012; Murtinah, Marjenah, 


\section{Hubungan Faktor Abiotik Terhadap Jumlah Klorofil dan Stomata (Ekofisiologis) pada Tanaman Jati (Tectona grandis L.f.) di Desa Sukodadi, Malang}

Amir Syarifuddin, Febri Arif Cahyo Wibowo, Saddam Affandy Yusuf, dan/and Agus Dwi Sulistyono

Ruchaemi, \& Daddy, 2015), pengujian dinamika bonita jati (Riyatno, Waluya, \& Pahlana, 2012) dan pengaplikasian mikoriza di persemaian (Rumondang \& Setiadi, 2011). Upaya-upaya tersebut merupakan langkah penting untuk menentukan tindakan silvikultur jati agar lebih mengoptimalkan pertumbuhan jati.

Bentuk optimalisasi pertumbuhan jati memperhatikan ekofisiologi tanaman dimana ekofisiologi didasarkan pada hubungan fisiologi tanaman (internal) dengan faktor lingkungan (eksternal). Keterkaitan hubungan tersebut adalah fisiologi tanaman dapat dipengaruhi oleh faktor luar, yakni faktor lingkungan di sekitar tempat tumbuh tanaman tersebut.

Tanaman membutuhkan lingkungan dan syarat tertentu agar dapat tumbuh secara optimal. Dari berbagai upaya tersebut belum ada evaluasi pada tingkat ekofisiologi jati untuk melihat apakah fisiologi jati dipengaruhi oleh berbagai faktor abiotik tersebut. Tujuan penelitian ini adalah mengetahui tingkat ekofisiologi jati yang dipengaruhi oleh beberapa faktor abiotik. Oleh karena itu, penelitian ini penting untuk dilakukan sebagai upaya rekomendasi tindakan silvikultur untuk mendukung optimalisasi pertumbuhan pohon jati.

\section{METODOLOGI}

\section{A. Lokasi dan Waktu Penelitian}

Lokasi penelitian dilaksanakan di Desa Sukodadi Kecamatan Wagir, Malang bulan Agustus-Oktober 2019. Tanaman jati yang ditanam merupakan semai yang berasal dari biji. Jarak tanam yang diterapkan oleh masyarakat adalah $2 \mathrm{~m}$ x $2 \mathrm{~m}$. Tanaman jati di lokasi penelitian memiliki rata-rata tinggi $11 \mathrm{~m}$ dan diameter $13 \mathrm{~cm}$. Tanaman jati yang diteliti berumur 6 tahun dengan kondisi yang tidak terawat.

Sampel pohon diambil dari 2 lokasi petak (berdekatan), dimana setiap petak dilakukan pengambilan sampel klorofil dan stomata dari 3 pohon terpilih dengan ulangan sebanyak 3 kali, sehingga didapatkan 18 data setiap klorofil dan stomata. Pengukuran suhu dan kelembapan dilakukan setiap satu minggu dan di akhir data dirata-rata, sehingga membentuk suhu dan kelembapan rata-rata lokasi. Pengambilan sampel tanah dilakukan satu kali untuk mendapatkan deskriptif kondisi hara pada tanah.

\section{B. Metode}

\section{Pengukuran suhu dan kelembapan}

Produktivitas hutan dipengaruhi oleh berbagai faktor antara lain kandungan hara tanah, tekstur dan struktur tanah, kelembapan, suhu, dan topografi (Anas \& Kholibrina, 2017). Pengukuran suhu dan kelembapan dilakukan pagi hari pukul 08.00-10.00 WIB menggunakan alat digital higrometer termometer selama 2 bulan. Pengukuran dilakukan setiap satu minggu yang selanjutnya menjadi data suhu dan kelembapan rata-rata.

\section{Pengambilan sampel}

Pengambilan sampel daun dilakukan terlebih dahulu dan dilanjutkan pengamatan data faktor abiotik selama 2 bulan. Pada lokasi penelitian dilakukan pengambilan sampel tanah dan sampel daun. Sampel tanah diambil sampai dengan kedalaman 30 $\mathrm{cm}$ dan setiap titik sampel diambil $1 \mathrm{~kg}$ tanah sebelum dikompositkan. Sampel tanah yang dianalisis merupakan komposit lima titik tanah yang diambil di lokasi. Lima titik sampel yang diambil dan dikompositkan yang dibawa ke laboratorium sebanyak $1 \mathrm{~kg}$.

Pengambilan sampel daun segar untuk sampel indeks stomata dan klorofil dilakukan pada pagi hari diantara pukul 09.00-10.00 (Nishiyama \& Murata, 2014). Pohon yang terpilih memiliki kriteria tinggi pohon 11-13 m. Sampel daun yang diambil pada ketinggian di atas 1-2 $\mathrm{m}$ dari permukaan tanah. Setiap pohon dipilih cabang atau ranting secara acak, daun yang diambil berada di bagian tengah dari ujung ranting karena daun yang sudah dewasa. Pengambilan sampel daun dilakukan 
dengan mengambil daun yang berumur sedang (fully expanded leaf) (Wibowo, Suryanto, \& Faridah, 2019).

Sampel helai daun dipilih searah, yaitu utara dan selatan atau barat dan timur. Total sampel daun yang diambil sebanyak 36 sampel, yaitu 18 untuk sampel indeks stomata dan 18 untuk sampel jumlah klorofil. Transportasi daun dilakukan dengan melindungi daun menggunakan plastik klip yang kedap udara, selanjutnya dimasukkan ke dalam box yang berisi es batu untuk menjaga daun tersebut tidak menguap.

\section{Analisis Ekofisiologi}

\section{Analisis indeks stomata}

Pembuatan preparat untuk pengamatan indeks stomata pada daun tanaman jati. Permukaan bawah daun dioleskan kuteks/cat kuku transparan lalu dibiarkan mengering. Cetakan stomata akan tercetak pada kuteks. Cetakan kuteks diangkat dari daun dengan menempelkan selotip pada kuteks. Selotip dilepaskan dari daun dan diletakkan di atas obyek glass. Preparat diamati di bawah mikroskop dengan perbesaran 400x. Indeks stomata dapat dihitung dengan menggunakan rumus di bawah dengan langkah awal menghitung jumlah sel epidermis dan stomata (Widianti, Violita, \& Chatri, 2017):

IS $(\%)=\frac{j u m l a h \text { stomata }}{\text { sel epidermis }+ \text { jumlah stomata }} \times 100$

\section{Analisis kandungan klorofil}

Sebanyak 0,1 gram daun tanaman jati dihancurkan menggunakan mortar sampai halus. Kemudian ditambahkan $10 \mathrm{ml}$ larutan aseton $80 \%$ dengan perbandingan berat sampel dan aseton 1:100. Selanjutnya larutan diambil dengan cara disaring dengan kertas saring dan dimasukkan ke dalam tabung reaksi. Mulut tabung reaksi ditutup dengan alumunium foil untuk menghindari penguapan. Larutan diukur dengan alat spektrofotometer pada panjang gelombang $646 \mathrm{~nm}$ dan $663 \mathrm{~nm}$. Jumlah klorofil a, jumlah klorofil $b$, dan total jumlah klorofil per gram daun jati dihitung menggunakan rumus (Arnon, 1949) :

$\mathrm{A}=\left[12,7\left(\mathrm{D}_{663}\right)-2,69\left(\mathrm{D}_{646}\right)\right](\mathrm{mg} / \mathrm{L})$

$\mathrm{B}=\left[22,9\left(\mathrm{D}_{646}\right)-4,68\left(\mathrm{D}_{663}\right)\right](\mathrm{mg} / \mathrm{L})$

$\mathrm{C}=\left[20,2\left(\mathrm{D}_{646}\right)-8,02\left(\mathrm{D}_{663}\right)\right](\mathrm{mg} / \mathrm{L})$

Keterangan:

A : Jumlah klorofil a

B : Jumlah klorofil b

C : Jumlah klorofil total

D : Panjang gelombang $(646 \mathrm{~nm}, 663 \mathrm{~nm})$

Pengujian dan analisis sampel tanah dilakukan di laboratorium Balai Pengkajian Teknologi Pertanian Malang. Komponen yang dianalisis meliputi unsur hara makro $\mathrm{N}$, P, dan K.

\section{Analisis data}

Pengaruh faktor abiotik terhadap fisiologi jati dianalisis menggunakan metode SEM-PLS (Structural Equation Modelling-Partial Least Square) Regression. Partial Least Square adalah suatu teknik statistik multivariat yang bisa untuk menangani banyak variabel respon serta variabel eksplanatori sekaligus. PLS tidak membutuhkan data yang berdistribusi normal (Alfa, Rachmatin, \& Agustina, 2017). Penjelasan variabel pada Tabel 1 .

Tabel (Table) 1 Keterangan variabel dependen dan independen (Information on the dependent and independent variables)

\begin{tabular}{cl}
\hline Variabel (Variables) & Keterangan (Information) \\
\hline X1 & Suhu (Temperature) \\
X2 & Kelembapan (Moisture) \\
Y1 & Jumlah klorofil a (Amount of chlorophyll $a)$ \\
Y2 & Jumlah klorofil b (Amount of chlorophyll $b$ ) \\
Y3 & Jumlah klorofil total (Total chlorophyll) \\
Y4 & Indeks stomata (Stomata Index) \\
\hline
\end{tabular}


Variabel tersebut dilanjutkan analisis SEM-PLS menggunakan software Warppls. Dari penggunaan analisis data ini akan didapat data Model PLS, Croncbach's Alpha, Goodness of Fit Model, pengujian hipotesis, dan konversi diagram jalur

\section{III.Hasil Dan Pembahasan}

\section{A. Hasil}

Berdasarkan data yang diperoleh di lapang seperti Gambar 1 - 4. Terdapat data fisiologi klorofil a, klorofil b, klorofil total dan indeks stomata, sedangkan data lingkungan terdapat suhu dan kelembapan.
Berdasarkan data pengamatan di lapang terdapat data kondisi unsur hara pada Tabel 2.

\section{Kondisi unsur hara}

Unsur hara yang dianalisis adalah $\mathrm{N}, \mathrm{P}$, dan K. Berdasarkan pengelompokan kriteria sifat kimia tanah menurut kandungan nitrogen sebesar $0,05 \%$ tergolong harkat sedang: kandungan $\mathrm{P}$ sebesar $19 \mathrm{ppm}$ tergolong harkat tinggi dan kandungan $\mathrm{K}$ $5,58 \mathrm{meq} / 100 \mathrm{~g}$ tergolong harkat sangat tinggi (Balai Penelitian Tanah, 2009). Dengan melihat kandungan unsur hara tanah, lokasi penelitian memiliki tingkat kesuburan tinggi.

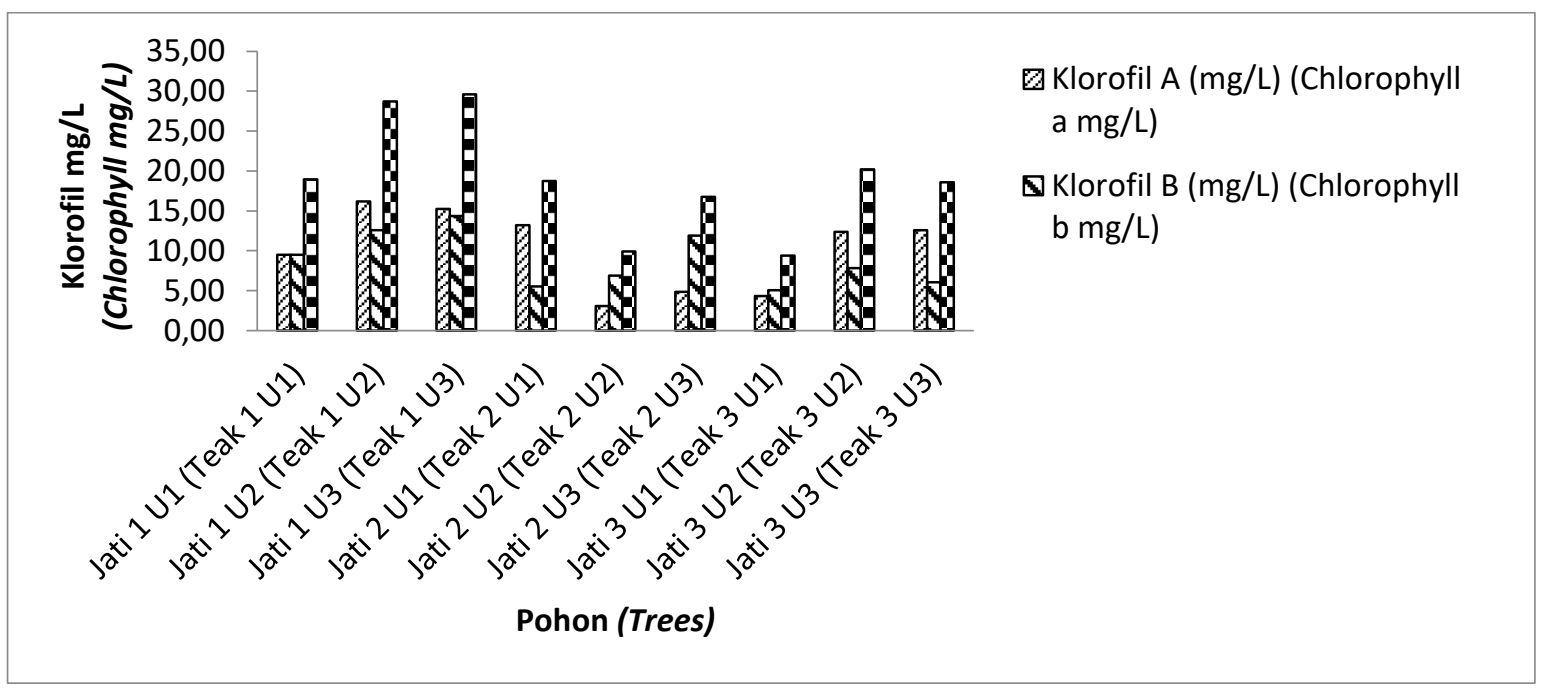

Gambar (Figure) 1. Data klorofil (Chlorophyll data)

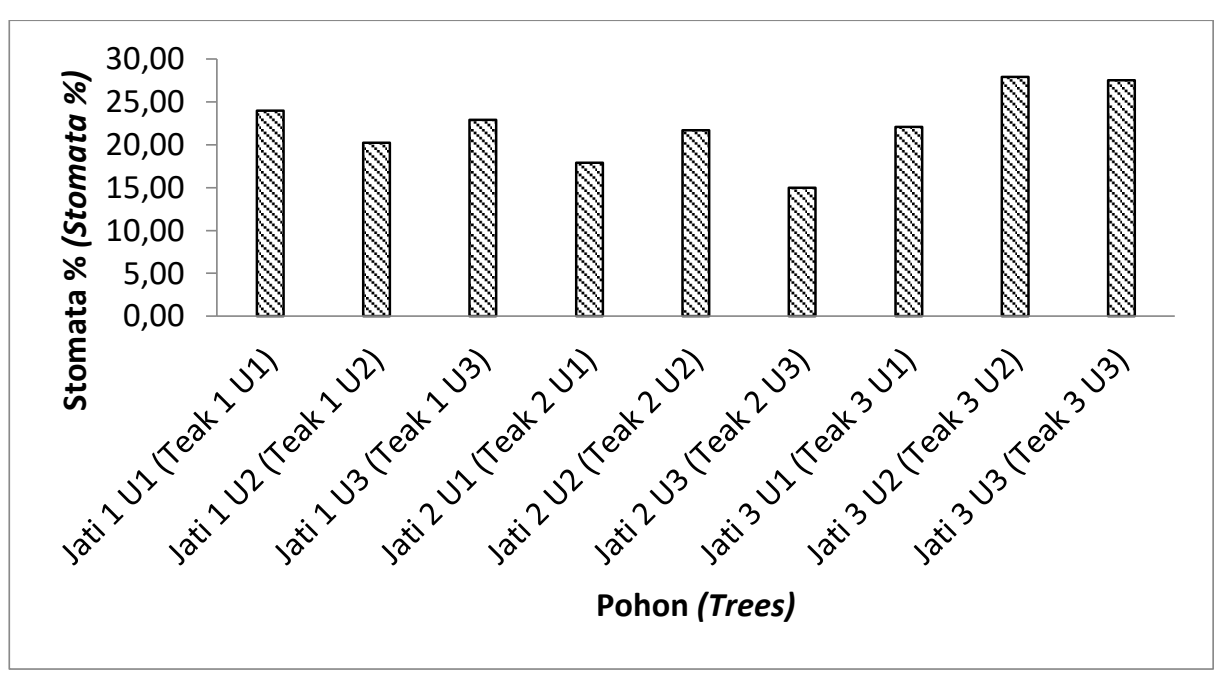

Gambar (Figure) 2. Indeks stomata (Stomata index) 


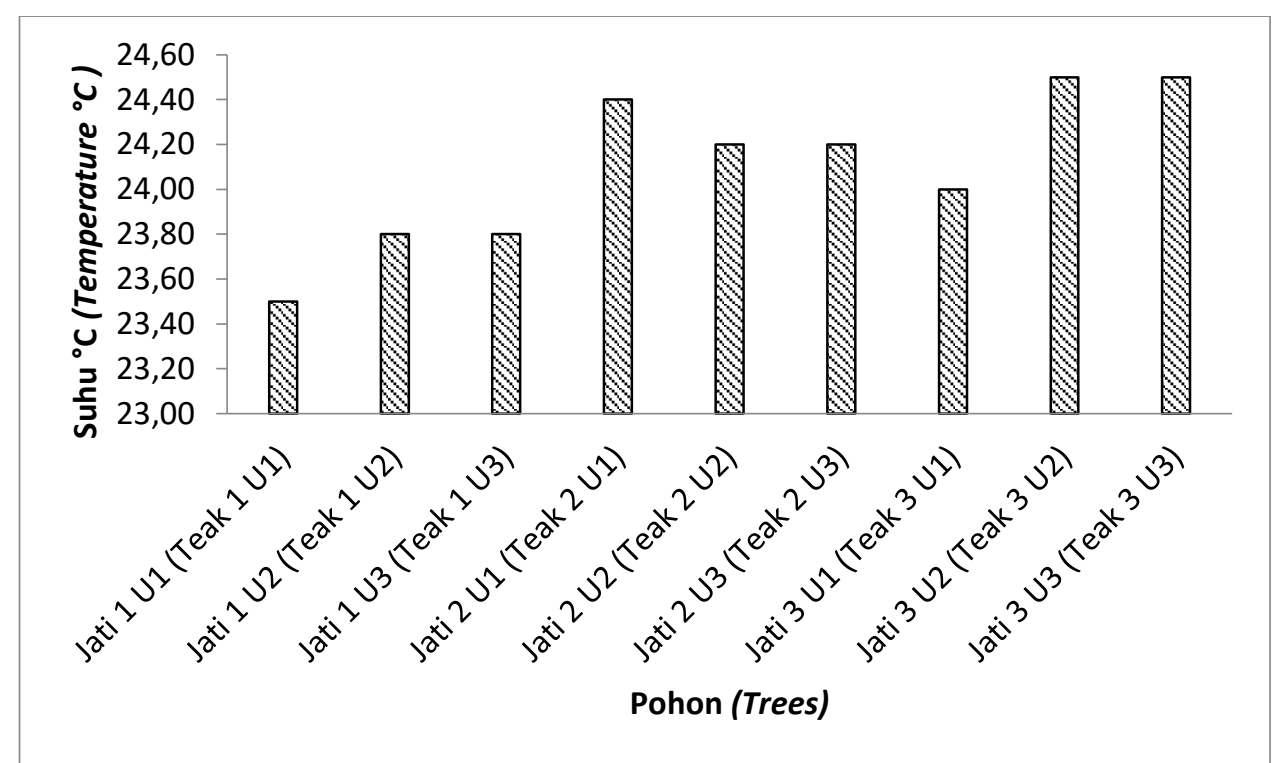

Gambar (Figure) 3. Data suhu (Temperature data)

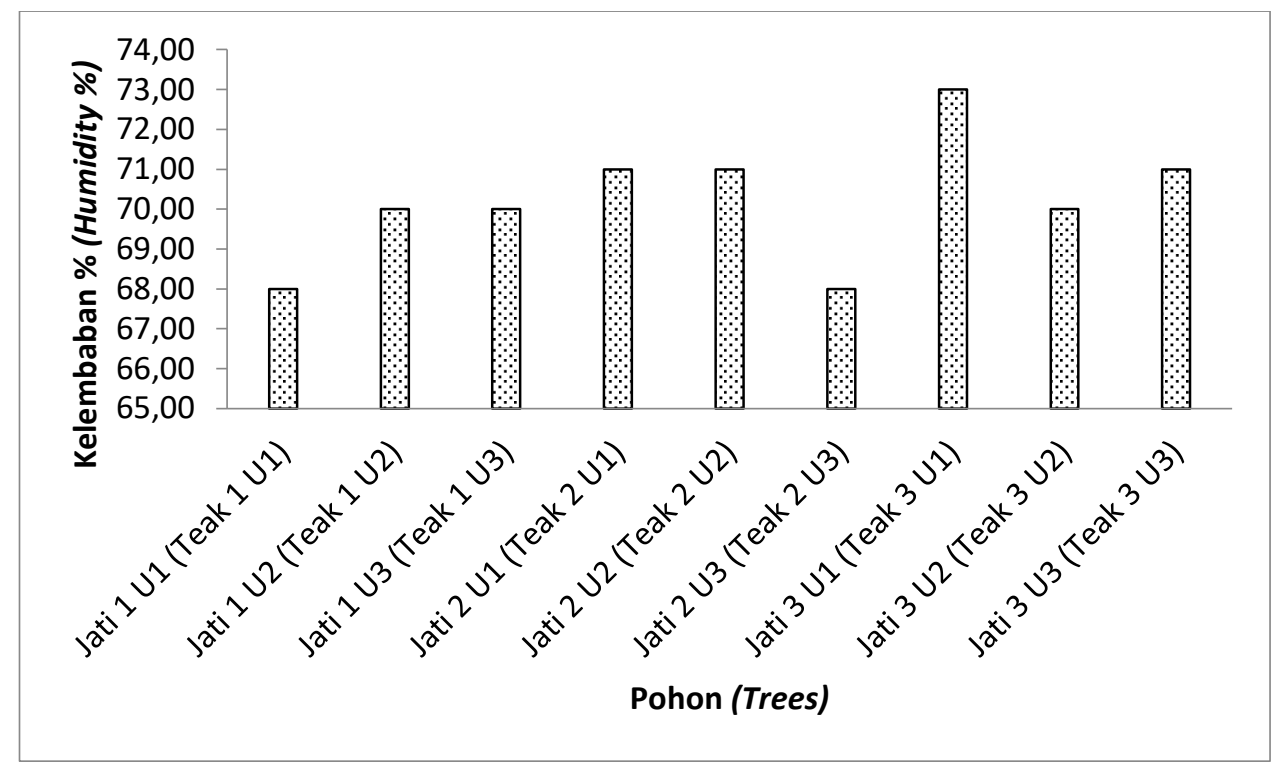

Gambar (Figure) 4. Data kelembapan (Humidity data)

Tabel (Table) 2. Kandungan unsur hara tanah (Soil nutrient content)

\begin{tabular}{ccc}
\multicolumn{3}{c}{ Unsur hara (Nutrient) } \\
\hline $\mathrm{N}(\%)$ & $\mathrm{P}(\mathrm{ppm})$ & $\mathrm{K}(\mathrm{meq} / 100 \mathrm{~g})$ \\
0,05 & 19 & 5,58 \\
\hline
\end{tabular}




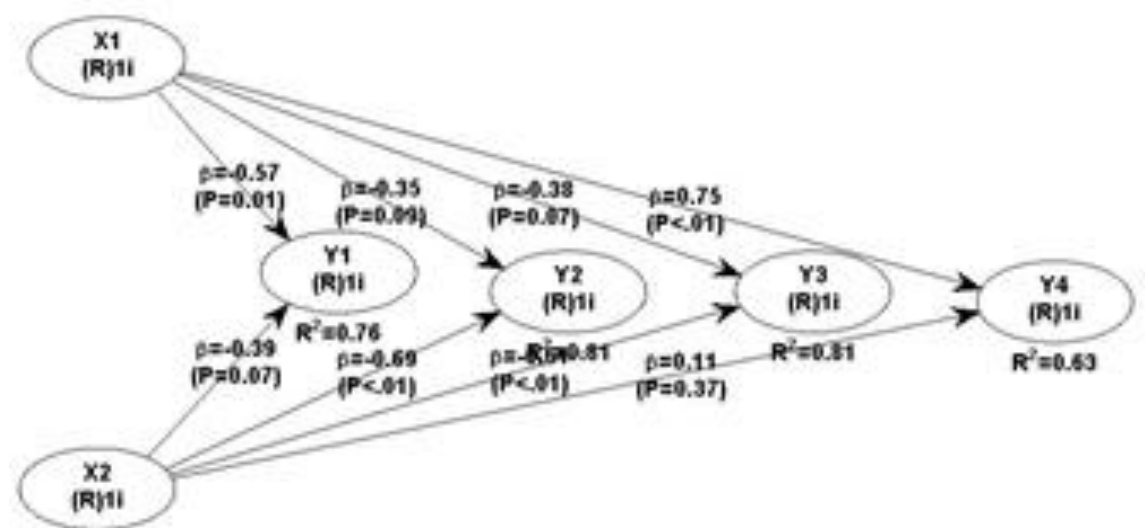

Gambar (Figure) 5. Model PLS pengaruh Y1 (jumlah klorofil a), Y2 (jumlah klorofil b), Y3 (klorofil tot) dan Y4 (indeks stomata) terhadap X1 (suhu) dan X2 (kelembapan) (PLS model) (The PLS model with Y1 (amount of chlorophyll a), Y2 (amount of chlorophyll b), Y3 (chlorophyll tot) and Y4 (stomata index) effects on X1 (temperature) and X2 (humidity) (PLS model)

Tabel (Table) 3. Cronbach's alpha (Cronbach's alpha)

\begin{tabular}{lc}
\hline Variabel (Variables) & Cronbach's alpha \\
\hline Suhu (Temperature) & 1 \\
Kelembapan (Humidity) & 1 \\
Jumlah klorofil a (Amount of chlorophyll a) & 1 \\
Jumlah klorofil b (Amount of chlorophyll b) & 1 \\
Jumlah klorofil total (Total chlorophyll) & 1 \\
Indeks Stomata (Stomata index) & 1 \\
\hline
\end{tabular}

Tabel (Table) 4. Model goodness of fit (Goodness of fit model)

\begin{tabular}{lcc}
\hline \multicolumn{1}{c}{ Variabel terikat (Dependent variable) } & $R$-squared & $Q$-squared \\
\hline Jumlah klorofil a (Amount of chlorophyll a) & 0,763 & 0,780 \\
Jumlah klorofil b (Amount of chlorophyll b) & 0,812 & 0,828 \\
Jumlah klorofil total (Total chlorophyll) & 0,814 & 0,837 \\
Indeks stomata (Stomata index) & 0,629 & 0,611 \\
\hline
\end{tabular}

\section{Analisis Partial Least Square (PLS)}

Gambar 5 di atas menunjukkan menunjukkan model dari variabel besaran pengaruh $\mathrm{X} 1$ atau $\mathrm{X} 2$ dari hasil $\mathrm{R}^{2}$ terhadap Y1, Y2, Y3, dan Y4. Variabel X1 dan X2 berpengaruh terhadap Y1 (76\%), Y2 (81\%), Y3 $(81 \%)$ dan Y4 (63\%).

Tabel 2 menunjukkan bahwa hasil Cronbach's alpha memberikan nilai 1 untuk semua variabel yang diuji. Hasil analisis dinyatakan konsisten (reliable) bila nilai Cronbach's alpha > 0,6, sehingga pada penelitian ini semua variabel yang dinyatakan konsisten (reliable).

\section{Goodness of fit model}

Goodness of fit model digunakan untuk mengetahui besarnya kemampuan variabel bebas untuk menjelaskan keragaman variabel terikat, atau dengan kata lain untuk mengetahui besarnya kontribusi variabel bebas terhadap variabel terikat. Goodness of fit model dalam analisis PLS dilakukan dengan menggunakan koefisien determinasi (R-Square) dan $Q$-Square predictive relevance $\left(Q^{2}\right)$. $R$ Square digunakan untuk menyatakan koefisien determinasi menyatakan seberapa besar pengaruh variabel bebas terhadap variabel terikat, 
sedangkan $Q$ Square untuk mengetahui kapabilitas prediksi.

$R$-square variabel jumlah klorofil a bernilai 0,763 atau $76,3 \%$. Hal ini dapat menunjukkan bahwa keragaman jumlah klorofil a mampu dijelaskan oleh suhu dan kelembapan sebesar $76,3 \%$ atau dengan kata lain kontribusi suhu dan kelembapan terhadap jumlah klorofil a sebesar 76,3\%, sedangkan sisanya sebesar 23,3\% merupakan kontribusi faktor lain yang tidak diuji dalam penelitian ini. $R$-square jumlah klorofil b $(81,2 \%)$ dan jumlah klorofil total $(81,4 \%)$. Kemudian $Q$-square variabel jumlah klorofil a bernilai 0,780. Hal ini menunjukkan bahwa suhu dan kelembapan memiliki kekuatan prediksi yang relevan dan semakin baik jika nilai $Q$-square mendekati 1 (Harliawan, Yasa \& Dewi, 2017), sehingga prediksi terhadap jumlah klorofil a tergolong harkat baik. $Q$-square jumlah klorofil b $(0,828)$ dan jumlah klorofil total $(0,834)$.

$R$-square variabel Indeks stomata bernilai 0,629 atau $62,9 \%$. Hal ini dapat menunjukkan bahwa keragaman indeks stomata mampu dijelaskan oleh suhu dan kelembapan sebesar $62,9 \%$ atau dengan kata lain kontribusi suhu dan kelembapan terhadap indeks stomata sebesar 62,9\%, sedangkan sisanya sebesar $37,1 \%$ merupakan kontribusi faktor lain yang tidak diuji dalam penelitian ini. Kemudian $Q$ square variabel indeks stomata bernilai 0,611 . Hal ini menunjukkan bahwa suhu dan kelembapan memiliki kekuatan prediksi yang besar terhadap indeks stomata.

\section{Pengujian hipotesis}

Pengujian hipotesis digunakan untuk menguji ada tidaknya pengaruh variabel bebas terhadap variabel terikat. Kriteria pengujian menyatakan bahwa apabila nilai $p$ value $\leq$ level of significance (alpha $=5 \%)$, maka dinyatakan adanya pengaruh yang signifikan variabel eksogen terhadap variabel endogen. Hasil pengujian hipotesis dapat diketahui melalui Tabel 5.

Tabel (Table) 5. Pengujian hipotesis (Hypothesis testing)

\begin{tabular}{|c|c|c|c|c|}
\hline Eksogen & Endogen & $\begin{array}{c}\text { Path } \\
\text { Coefficient }\end{array}$ & $\begin{array}{l}\text { Standard } \\
\text { Error }\end{array}$ & $\begin{array}{c}P- \\
\text { Values }\end{array}$ \\
\hline $\begin{array}{l}\text { Suhu } \\
\text { (Temperature) }\end{array}$ & $\begin{array}{l}\text { Jumlah klorofil a (Amount } \\
\text { of chlorophyll a) }\end{array}$ & $-0,571$ & 0,199 & 0,010 \\
\hline $\begin{array}{l}\text { Suhu } \\
\text { (Temperature) }\end{array}$ & $\begin{array}{l}\text { Jumlah klorofil b (Amount } \\
\text { of chlorophyll b) }\end{array}$ & $-0,353$ & 0,242 & 0,091 \\
\hline $\begin{array}{l}\text { Suhu } \\
\text { (Temperature) }\end{array}$ & $\begin{array}{l}\text { Jumlah klorofil total (Total } \\
\text { chlorophyll) }\end{array}$ & $-0,382$ & 0,236 & 0,072 \\
\hline Suhu & Indeks stomata (Stomata & & & \\
\hline (Temperature) & Index) & 0,746 & 0,170 & 0,001 \\
\hline $\begin{array}{l}\text { Kelembapan } \\
\text { (Humidity) }\end{array}$ & $\begin{array}{l}\text { Jumlah klorofil a (Amount } \\
\text { of chlorophyll a) }\end{array}$ & $-0,387$ & 0,235 & 0,069 \\
\hline $\begin{array}{l}\text { Kelembapan } \\
\text { (Humidity) }\end{array}$ & $\begin{array}{l}\text { Jumlah klorofil b (Amount } \\
\text { of chlorophyll b) }\end{array}$ & $-0,688$ & 0,179 & 0,002 \\
\hline $\begin{array}{l}\text { Kelembapan } \\
\text { (Humidity) }\end{array}$ & $\begin{array}{l}\text { Jumlah klorofil total (Total } \\
\text { chlorophyll) }\end{array}$ & $-0,614$ & 0,191 & 0,006 \\
\hline $\begin{array}{l}\text { Kelembapan } \\
\text { (Humidity) }\end{array}$ & $\begin{array}{l}\text { Indeks stomata (Stomata } \\
\text { index) }\end{array}$ & 0,105 & 0,303 & 0,369 \\
\hline
\end{tabular}


Hubungan Faktor Abiotik Terhadap Jumlah Klorofil dan Stomata
(Ekofisiologis) pada Tanaman Jati (Tectona grandis L.f.) di Desa Sukodadi, Malang

Amir Syarifuddin, Febri Arif Cahyo Wibowo, Saddam Affandy Yusuf, dan/and Agus Dwi Sulistyono

Tabel (Table) 6. Konversi diagram jalur (Conversion of path diagram)

\begin{tabular}{llc}
\hline \multicolumn{1}{c}{ Eksogen } & \multicolumn{1}{c}{ Endogen } & Path Coefficient \\
\hline $\begin{array}{l}\text { Suhu (Temperature) } \\
\text { Suhu (Temperature) }\end{array}$ & Jumlah klorofil a (Amount of chlorophyll a) & $-0,571$ \\
$\begin{array}{l}\text { Suhu (Temperature) } \\
\text { Suhu (Temperature) }\end{array}$ & Jumlah klorofil b (Amount of chlorophyll b) & $-0,353$ \\
$\begin{array}{l}\text { Kelembapan } \\
\text { (Humidity) }\end{array}$ & Jumlah klotorofil a (Amount of chlorophyll a) & $-0,382$ \\
$\begin{array}{l}\text { Kelembapan } \\
\text { (Humidity) }\end{array}$ & Jumlah klorofil b (Amount of chlorophyll b) & 0,746 \\
$\begin{array}{l}\text { Kelembapan } \\
\text { (Humidity) }\end{array}$ & Jumlah klorofil total (Total chlorophyll) & $-0,387$ \\
$\begin{array}{l}\text { Kelembapan } \\
\text { (Humidity) }\end{array}$ & Indeks stomata (Stomata index) & $-0,688$ \\
\hline
\end{tabular}

Uji hipotesis pengaruh suhu terhadap jumlah klorofil a, jumlah klorofil $b$, total dan indeks stomata menghasilkan Path Coefficient (koefisien jalur) yakni jumlah klorofil a (-0,571), jumlah klorofil b $(-0,353)$, jumlah klorofil total $(-0,382)$ dan indeks stomata $(0,746)$ dengan nilai $p$ value untuk jumlah klorofil a $(0,010)$, jumlah klorofil b (0,091), jumlah klorofil total $(0,072)$ dan indeks stomata $(0,001)$. Hasil pengujian tersebut menunjukkan signifikan dengan nilai $p$ value $<5 \%(0,05)$. Terdapat pengaruh yang signifikan suhu terhadap jumlah klorofil a dan indeks stomata.

Uji hipotesis pengaruh kelembapan terhadap jumlah klorofil a, jumlah klorofil $\mathrm{b}$, total dan indeks stomata menggambarkan hasil Path Coefficient (koefisien jalur) yakni jumlah klorofil a $(-0,387)$, jumlah klorofil b $(-0,688)$, jumlah klorofil total $(-0,614)$ dan indeks stomata $(0,105)$ dengan nilai $p$ value untuk jumlah klorofil a $(0,069)$, jumlah klorofil b (0,002), jumlah klorofil total $(0,006)$ dan indeks stomata $(0,369)$. Hasil pengujian tersebut menunjukkan signifikan dengan nilai $p$ value $<5 \%(0,05)$. Terdapat pengaruh suhu yang signifikan terhadap jumlah klorofil $b$ dan jumlah klorofil total.

\section{Konversi diagram jalur ke dalam model struktural}

Konversi diagram jalur dalam model pengukuran dimaksudkan untuk memprediksi pengaruh variabel eksogen terhadap variabel endogen sebagaimana disajikan dalam Tabel 6.

Berdasarkan Tabel 6 dapat diketahui bahwa model struktural yang terbentuk adalah:

Persamaan pertama: $\mathrm{Y} 1=-0,571 * \mathrm{X} 1-$ $0,387 \times 2$

a. Koefisien jalur suhu terhadap jumlah klorofil a sebesar $-0,571$ menggambarkan bahwa suhu memiliki pengaruh negatif dan signifikan. Hasil tersebut menunjukkan peningkatan suhu akan berpengaruh signifikan terhadap penurunan jumlah klorofil a.

b. Koefisien jalur kelembapan terhadap jumlah klorofil a sebesar $-0,387$ menyatakan bahwa kelembapan berpengaruh negatif dan tidak signifikan. Kelembapan dipengaruhi suhu, semakin tinggi suhu, maka kelembapan akan menurun. Berdasarkan hasil tersebut menunjukkan bahwa kelembapan ratarata $70,2 \%$ akan mengakibatkan penurunan pembentukan pada jumlah klorofil a. 
Persamaan kedua: $\mathrm{Y} 2=-0,353 \mathrm{X} 1-$ $0,688 * \mathrm{X} 2$

Dari persamaan di atas dapat menggambarkan bahwa:

a. Koefisien jalur suhu terhadap jumlah klorofil b sebesar -0,353 menyatakan bahwa suhu berpengaruh negatif dan tidak signifikan terhadap jumlah klorofil b. Tinggi suhu memberikan gambaran menurunkan kandungan jumlah klorofil b daun.

b. Koefisien jalur kelembapan terhadap jumlah klorofil b sebesar $-0,688$ menyatakan bahwa kelembapan berpengaruh negatif dan signifikan terhadap jumlah klorofil b. Hal ini menunjukkan kelembapan $70,2 \%$.

Persamaan ketiga: Y2 $=-0,362 \mathrm{X} 1-0,614 *$ X2

Dari persamaan di atas dapat menggambarkan bahwa:

a. Koefisien jalur suhu terhadap jumlah klorofil total sebesar $-0,362$ menyatakan bahwa suhu berpengaruh negatif dan tidak signifikan terhadap jumlah klorofil total. Tinggi suhu memberikan gambaran menurunkan kandungan jumlah klorofil total.

b. Koefisien jalur kelembapan terhadap jumlah klorofil total sebesar -0,614 menyatakan bahwa kelembapan berpengaruh negatif dan signifikan terhadap jumlah klorofil total. Hal ini menunjukkan kelembapan 70,2\% mengakibatkan pengaruh negatif sebesar -0,614 terhadap jumlah klorofil total.

Persamaan Keempat: $\mathrm{Y} 2=0,746^{*} \mathrm{X} 1+$ $0,105 \times 2$

Dari persamaan di atas dapat menggambarkan bahwa:

a. Koefisien jalur suhu terhadap jumlah klorofil total sebesar 0,746 menyatakan bahwa suhu berpengaruh positif dan signifikan terhadap indeks stomata. Semakin tinggi suhu memberikan gambaran meningkatkan jumlah bukaan stomata.

b. Koefisien jalur kelembapan terhadap jumlah klorofil total sebesar 0,105 menyatakan bahwa kelembapan berpengaruh positif dan tidak signifikan terhadap indeks stomata. Hal ini menunjukkan kelembapan 70,2\% mengakibatkan pengaruh positif terhadap stomata.

\section{B. Pembahasan}

\section{Pengaruh Suhu terhadap jumlah klorofil dan indeks stomata}

Hasil analisis yang menunjukkan suhu berpengaruh negatif secara signifikan terhadap jumlah klorofil a sebesar -0,571, sedangkan pengaruh suhu terhadap jumlah klorofil $b$ dan jumlah klorofil total tidak berpengaruh. Pada suhu rata-rata $24^{\circ} \mathrm{C}$ di lokasi penelitian memberikan pengaruh negatif terhadap jumlah klorofil a; apabila penambahan suhu dampak pemanasan global dapat meningkatkan suhu di Wagir melebih $24^{\circ} \mathrm{C}$, maka akan berdampak buruk terhadap pembentukan jumlah klorofil a pohon jati. Ketika suhu lingkungan berkurang, cahaya menjadi berlebihan akibat pengurangan aktivitas fotosistensis, sehingga terjadi produksi jumlah klorofil tereksitasi yang berlebihan, yang menghasilkan Reactive Oxygen Species (ROS) (Nishiyama \& Murata, 2014).

Peningkatan suhu berpengaruh positif secara signifikan terhadap laju indeks stomata. Suhu yang rendah dan kelembapan yang tinggi pada tempat ternaung dapat menyebabkan penurunan jumlah stomata (Budiono et al., 2016), namun pada jam 09.00-10.00 laju bukaan stomata mengalami peningkatan (Fatonah, Asih, Mulyanti, \& Iriani, 2013).

\section{Pengaruh kelembapan terhadap jumlah klorofil dan indeks stomata}

Pengaruh negatif secara signifikan oleh kelembapan terhadap jumlah klorofil b sebesar -0,688. Data kelembapan rata-rata di lokasi adalah 70,2\%. Apabila melihat dari hasil uji statistik, maka kelembapan $70,2 \%$ memiliki pengaruh negatif secara signifikan, sehingga kenaikan suhu lokasi akan diikuti dengan penurunan kelembapan 


\section{Hubungan Faktor Abiotik Terhadap Jumlah Klorofil dan Stomata (Ekofisiologis) pada Tanaman Jati (Tectona grandis L.f.) di Desa Sukodadi, Malang}

Amir Syarifuddin, Febri Arif Cahyo Wibowo, Saddam Affandy Yusuf, dan/and Agus Dwi Sulistyono

(Anam MS, Kurniati, \& Suharto, 2013). Kondisi penurunan kandungan jumlah klorofil pada daun merupakan kondisi, dimana tanaman akan mengoptimalkan jumlah klorofil a apabila tidak ternaungi, sedangkan pada kondisi ternaungi akan meningkatkan jumlah klorofil b (Wibowo et al., 2019).

Hasil interpretasi uji statistik menunjukkan pengaruh negatif secara siginifikan kelembapan terhadap jumlah klorofil total sebesar -0,614. Penurunan suhu lingkungan yang diikuti dengan kenaikan kelembapan mengakibatkan aktivitas fotosistem berkurang, sehingga terjadi produksi jumlah klorofil secara berlebihan dan menghasilkan oksigen reaktif (Pospisill \& Prasad, 2014). Secara tidak signifikan ditunjukkan oleh pengaruh kelembapan terhadap jumlah klorofil a dan indeks stomata. Pengaruh negatif terhadap jumlah klorofil a, sedangkan terhadap indeks stomata memiliki pengaruh positif namu keduanya tidak signifikan.

Solusi/perbaikan yang dapat dilakukan adalah menerapkan teknik silvikultur yang baik dengan pengaturan jarak tanaman yang sesuai untuk menurunkan suhu dan meningkatkan kelembapan iklim mikro di kawasan. Pohon jati yang diteliti merupakan pohon milik petani yang ditanam tanpa dilakukan pengaturan jarak tanaman dan perawatan. Selain itu penerapan sistem agroforestri di bawah tegakan bisa dikombinasikan dalam teknik silvikultur untuk menurunkan suhu dan menaikkan kelembapan dalam kawasan.

\section{KESIMPULAN DAN SARAN}

\section{A. Kesimpulan}

Kelembapan berpengaruh signifikan terhadap jumlah klorofil $b$ dan jumlah klorofil total pohon jati, sedangkan suhu berpengaruh secara signifikan terhadap jumlah klorofil a dan indeks stomata. Solusi perbaikan dengan penerapan teknik silvikltur dalam pengaturan jarak tanaman yang sesuai untuk menurunkan suhu dan meningkatkan kelembapan iklim mikro di kawasan.

\section{B. Saran}

Untuk mengoptimalkan pemanfaatan lahan dan meningkatkan produktivitas hutan jati dapat dilakukan dengan cara pengaturan jarak tanam dan penerapan agroforestri.

\section{UCAPAN TERIMA KASIH}

Kami ucapkan terima kasih kepada Universitas Muhammadiyah Malang yang telah mendanai penelitian ini melalui skema Blockgrant FPP UMM.

\section{DAFTAR PUSTAKA}

Adinugraha, H.A., \& Fauzi, M.A. (2015). Pertumbuhan klon jati asal cepu dan madiun umur 10 tahun pada lahan berbatu di Gunung Kidul. Jurnal Hutan Tropis, 3(3), 253-259. Retrieved from https://media.neliti.com/media/publica tions/83024-ID-pertumbuhan-klonjati-asal-cepu-dan-madi.pdf

Ai Song, N., \& Banyo, Y. (2011). Konsentrasi klorofil daun sebagai indikator kekurangan air pada tanaman. Jurnal Ilmiah Sains, 11(2), 166-173.

Alfa, A.A.G., Rachmatin, D., \& Agustina, F. (2017). Analisis pengaruh faktor keputusan konsumen dengan structural equation modeling partial least square. Jurnal Eureka Matika, 5(2), 59-71. Retrieved

from https://ejournal.upi.edu/index. php/JEM/article/view/9599

Anam, M.M., Kurniati, E., \& Suharto, B. (2013). Penurunan kandungan logam $\mathrm{pb}$ dan $\mathrm{cr}$ leachate melalui fitoremediasi bambu air (equisetum hyemale) dan zeolit. Jurnal Keteknikan Pertanian Tropis Dan Biosistem, 1(2), 43-59.

Anas, A., \& Kholibrina, C.R. (2017). Faktor-faktor fenotipe dan lingkungan 
penentu produktivitas resin kemenyan toba (Styrax sumatrana J. J. Sm). Jurnal Penelitian Kehutanan Sumatrana, 1(1), 1-9. Retrieved from https://ejournal.fordamof.org/ejournal-litbang/index.php/ JPKS/article/view/2613

Arnon, D.I. (1949). Copper enzymes in isolated chloroplasts polyphenoloxidase in beta vulgaris. Plant Physiology, 24(1).

Budiono, R., Sugiarti, D., Nurzaman, M., Setiawati, T., Supriatun, T., \& Zainal, A. (2016). Kerapatan stomata dan kadar klorofil tumbuhan clausena excavata berdasarkan perbedaan intensitas cahaya. Seminar Nasional Pendidikan Dan Saintek, 61-65.

Fatonah, S., Asih, D., Mulyanti, D., \& Iriani, D. (2013). Penentuan waktu pembukaan stomata pada gulma melastoma malabathricum L. di perkebunan gambir Kampar, Riau. Jurnal Biospecies, 6(2), 15-22. Retrieved from https://www.onlinejournal.unja.ac.id/index.php/biospecie s/article/view/886

Fitriani, A. (2012). Evaluation of plant growth in teak on national movement for forest and land rehabilitation. Jurnal Hutan Tropis, 13(1), 55-61. Retrieved from https://ppjp.ulm.ac.id /journal/index.php/jht/article/view/14 95

Harliawan, H., Yasa, IGW Murjana., \& Hardiwinoto, Made HU. (2017). Pengaruh kompensasi, pendidikan dan program kesejahteraan terhadap produktivitas kerja wartawan di Provinsi Bali. E-Jurnal Ekonomi dan Bisnis Universitas Udayana, (2017): 2697-2730.

Hasanbahri, S., Marsono, D., \& Hardiwinoto, S. (2014). Serangan Benalu pada beberapa kelas umur tanaman jati di wilayah hutan BKPH Begal, KPH Ngawi, Jawa Timur. Jurnal Manusia Dan Lingkungan, 21(2), 195-201.

Izza, F., \& Laily, A.N. (2015). Karakteristik stomata tempuyung (sonchus arvensis L.) dan hubungannya dengan transpirasi tanaman di Universitas Islam Negeri (UIN) Maulana Malik Ibrahim Malang Stomatal Characteristic of Sonchus arvensis L. and Its Relation With Transpiration in Isla. Seminar Nasional Konservasi Dan Pemanfaatan Sumber Daya Alam 2015, 177-180. Retrieved from https://www.neliti.com/id/publications /170571/karakteristik-stomatatempuyung-sonchus-arvensis-1-danhubungannya-dengan-transp

Juairiah, L. (2014). Studi karakteristik stomata beberapa jenis tanaman revegetasi di lahan pasca penambangan timah di Bangka. Jurnal Widyariset, 17(2), 213-218. Retrieved fromhttps://www.online-journal.unja. ac.id/index.php/biospecies/article/vie w/886

Karubuy, C.N. Rahmadaniarti, A., \& Wanggai, J. (2018). Karakteristik stomata dan kandungan klorofil daun anakan kayu cina (sundacarpus amarus blume C.N.Page) pada beberapa intensitas naungan. Jurnal Kehutanan Papuasia, 4(1), 45-56.

Murtinah, V., Marjenah, Ruchaemi, A., \& Daddy, R. (2015). Pertumbuhan hutan tanaman jati (tectona grandis Linn.f.) di Kalimantan Timur. Jurnal AGRIFOR, XIV(2), 287-292. Retrieved from https://media.neliti.com/media/publica tions/30143-ID-pertumbuhan-hutantanaman-jati-tectona-grandis-linnf-dikalimantan-timur.pdf

Nishiyama, Y., \& Murata, N. (2014). Revised scheme for the mechanism of photoinhibition and its application to enhance the abiotic stress tolerance of the photosynthetic machinery. Journal Appl Microbiol Biotechnol, 1. https://doi.org/10.1007/s00253-0146020-0

Pospisill, P., \& Prasad, A. (2014). Formation of singlet oxygen and protection against its oxidative damage 
in Photosystem II under abiotic stress Pavel. Journal of Photochemistry \& Photobiology.

https://doi.org/10.1016/j.jphotobiol.20 14.04.025

Prehaten, D., Indrioko, S., Hardiwinoto, S., Na'iem, M., \& Supriyono, H. (2018). Pengaruh beberapa karakteristik kimia dan fisika tanah pada pertumbuhan 30 famili uji keturunan jati (tectona grandis Linn F) umur 10 tahun. Jurnal Ilmu Kehutanan, 12, 52-60. Retrieved from https://jurnal.ugm.ac.id/jikfkt/ article/view/34109

Riyatno, H.D., Waluya, U., \& Pahlana, H. (2012). Kajian evaluasi lahan hutan jati sistem bonita di Kesatuan Pemangku Hutan (KPH) CEPU. Jurnal Penelitian Hutan Tanaman, 9(1), 43-50.

Rumondang, J., \& Setiadi, Y. (2011). Evaluasi aplikasi fungi mikoriza arbuskula (FMA) dan respon pertumbuhannya terhadap jati (tectona grandis Linn F) di persemaian. Jurnal Silvikultur Tropika, 2(3), 194-197. Retrieved from https://journal.ipb.ac. id/index.php/jsilvik/article/view/5386

Shu-yue, Y.I.N., Tao, W., Wei, H.U.A., Jiapeng, M., Yong-qi, G.A.O., \& Yuanhai, F.U. (2020). ScienceDirect Midsummer surface air temperature and its internal variability over China at 1.5 $\mathrm{C}$ and $2 \mathrm{C}$ global warming. Advances in Climate Change Research, $(\mathrm{xxxx})$. https://doi.org/10.1016/j.accre.2020.0 9.005

Strobl, S., Cueva, E., Silva, B., Knuesting, J., Schorsch, M., Scheibe, R., ... Beck, E. (2016). Water relations and photosynthetic water use efficiency as indicators of slow climate change effects on trees in a tropical mountain forest in South Ecuador. Ecological Indicators.

https://doi.org/10.1016/j.ecolind.2016. 12.021

Supriyo, H., \& Prehaten, D. (2014). Kandungan unsur hara dalam daun jati yang baru jatuh pada tapak yang berbeda. Jurnal Ilmu Kehutanan, 8(2), 49-52. Retrieved from https://jurnal.ugm.ac.id/jikfkt/article/v iew/10169

Tang, C.Q., Ohashi, H., Matsui, T., \& Herrando-, S. (2020). Effects of climate change on the potential distribution of the threatened relict Dipentodon sinicus of subtropical forests in East Asia : Recommendations for management and conservation, 23. https://doi.org/10.1016/j.gecco.2020.e 01192

Wibowo, F.A.C., Putri, R.S.M., Syarifuddin, A., \& Muttaqin, $\mathrm{T}$. (2020). Sistem perbaikan ekofisiologi tanaman ssengon (paraserianthes falcataria ( L ) Nielsen) di Kecamatan Wagir, Malang. Jurnal Hutan Tropis, 8(2), 161-171.

Wibowo, F.A.C., Suryanto, P., \& Faridah, E. (2019). Ekofisiologi dan peluang pengembangan durian (durio zibethinus ex Murray) dengan sistem agroforestri di lereng selatan Gunung Merapi, Indonesia. Jurnal Ilmu Kehutanan, 13, 195-209. Retrieved from https://jurnal.ugm.ac.id/jikfkt/ article/view/52441

Widianti, Putri., Violita, Violita., \& Chatri, Moralita. (2017). Luas dan indeks stomata daun tanaman padi (oriza sativa L) varietas cisokan dan batang piaman akibat cekaman kekeringan. Bioscience, 1(2), 77-86 2017.

Widiatmaka, Merdiranto, A., \& Hermanu, W. (2015). Karakteristik, klasifikasi tanah, dan pertumbuhan tanaman jati (Tectona grandis Linn f.) Var. unggul nusantara di Ciampea, Kabupaten Bogor. Jurnal Pengelolaan Sumber daya Alam Dan Lingkungan, 5(1), 8797. Retrieved from https://journal.ipb.ac.id/index.php/jpsl /article/view/10210

Zweifel, R., Regling, A., \& Dobbertin, M. (2009). Species-specific stomatal response of trees to drought - a link to vegetation dynamics? Journal of 
Vegetation Science, 20, 442-454.

Retrieved

from

https://www.researchgate.net/publicati on/227704389_Species-specific

stomatal_response_of_trees_to_droug ht_-_A_link_to_vegetation_dynamics 